\title{
Montessori Eğitim Yaklaşımının Din Eğitimine Uygulanması: Godly Play Örneği*
}

\section{Application of Montessori Educational Approach to Religious Education: The case of Godly Play**}

Cemil ORUÇ, Sorumlu Yazar, Doç. Dr.

İnönü Üniversitesi, İlahiyat Fakültesi.

Email: cemil.oruc@inonu.edu.tr

ORCID: 0000-0002-9870-8597

ISSN: 11303-880X

e-ISSN: 2667-7504

http://ded.dem.org.tr

Geliş/Received: 10.04.2019

Kabul/Accepted: 01.08 .2019

Makale Yayın: 25.12.2019

Makale Türü/Article Type:

Araştırma/Research
Atıf/Citation: Oruç, C. (2019). Montessori eğitim yaklaşımının din eğitimine uygulanması: Godly Play örneği. Değerler Eğitimi Dergisi, 17 (38), 235-266. DOI: 10.34234/ ded.552117

*Bu çalışma İnönü Üniversitesi Bilimsel Araştırma Projeleri Koordinasyon Birimince desteklenmiştir. Proje Numarasi: SBA-2019-1743

** This study was supported by Research Fund of the Inonu University. Project Number: SBA-2019-1743 
Öz: Maria Montessori çocuk eğitimi konusunda hem teorik hem de uygulama11 birçok çalışma gerçekleştirmiştir. Montessori'nin çalışmaları incelendiğinde hem çocuk eğitiminde hem de -çok bilinmemekle birlikte- din eğitiminde özgün girişimlerde bulunduğu görülür. Çalışmamız; Montessori'nin din eğitimi konusundaki uygulamalarını farklı yönleri ile ele almayı, Jerome W. Berryman'ın geliştirdiği Godly Play yaklaşımını teorik temeller ve uygulama süreçleri açısından incelemeyi amaçlamaktadır. Bu amaç doğrultusunda nitel araştırma yöntemi kullanılmıştır. Veriler doküman inceleme yolu ile toplanmıştır. Araştırma sonucunda, Montessori'nin yaklaşık 20 yıl kaldığı Barselona'da kurduğu okulda uygulamalı din eğitimine ayrı bir önem verdiği görülmüştür. Sistematik ve teorik bir din eğitiminin değil, çocukların gelişim düzeylerine göre düzenlenmiş uygun bir çevrede ve okul ortamında, tecrübeye ve çalışmaya dayalı bir din ve maneviyat eğitiminin mümkün olduğunu uygulamalı olarak göstermiştir. Onun eğitim anlayışııı daha sistematik bir hale getiren Berryman, bazı yönleriyle Montessori geleneğinden ayrılmakla birlikte, temelde Montessori'ye dayanan erken çocukluk dönemi din eğitiminin Protestan yorumunu geliştirmiştir. Bu yaklaşımda; İncil kıssalarının sınıf ortamında uygun materyaller ile sergilenebileceği ve bunların çocukların dünyasına dâhil edilebileceği iddia edilir. Bunu sağlamak için ayinlerden ziyade çocukların Tanrı'nın kelamı ile baş başa kalacakları ve ilgili materyalden kendi anlamlarını çıkaracakları Montessori sınıfları düzenlenmiştir. Çalışma sonucunda söz konusu yaklaşımın uygun yöntem ve içerik düzenlemeleri ile diğer dinler için de kullanılabileceği görülmüştür.

Anaht a r Kelimeler: Din eğitimi, Maria Montessori, Jerome W. Berryman, Godly Play, Erken çocukluk.

$\&$

Abstract: Maria Montessori carried out both theoretical and practical studies on child education. When Montessori's studies are examined, it is seen that she made original contributions both in education of children and - although not very well known - in religious education. The purpose of this study is to examine the different aspects of Montessori's practices on religious education and to examine the Godly Play approach developed by Berryman in terms of theoretical foundations and application processes. Qualitative research method was used for this purpose. Data was collected through document review. At the end of the study, it is concluded that Montessori gave special importance to applied religious education in the school she founded in Barcelona where she stayed for 20 years. She practically demonstrated that it is possible to study 
religion and spirituality based on experience and work in a suitable school environment which arranged according to the level of development of children, not a systematic and theoretical religious education. Berryman has developed her educational approach and made it more systematic. Although he has diverged markedly from the Montessori tradition, he has developed a Protestant interpretation of early childhood religious education. In this approach; it is claimed that the Bible stories can be included with appropriate materials in the classroom environment and they can be introduced to the world of children. In order to achieve this goal, the classes should be organized as Montessori's style, where children would be left alone with the word of God, and they would get meaning from the material themselves. As a result, it can be argued that this approach can be used for other religions with appropriate method and content arrangements.

Keywords: Maria Montessori, Jerome W. Berryman, Godly Play, Early childhood, Religious education.

\section{Giriş}

Eğitim alanında 20. yüzyılın en önemli aktörlerinden biri olan Maria Montessori (1870-1952) tıp alanındaki çalışmalardan eğitim ile ilgili konulara yönelmiş ve çocuk eğitimi konusunda kendi dönemi için oldukça ileri sayılabilecek birçok uygulamanın öncülüğünü yapmıştır. Montessori'nin eğitim anlayışı kendi döneminde olduğu gibi günümüzde de hala bazı güncellemelerle geçerliliğini korumakta ve etkisini sürdürmektedir.

Montessori eğitim yaklaşımı çerçevesinde din eğitimine ayrıca önem vermiş, bu konuda bazı uygulamalar gerçekleştirmiştir. Bu konudaki yaklaşımını Barselona okulunda gerçekleştirdiği uygulamalarda görmek mümkündür. Montessori kendisinin kurduğu bu okulda çocukların dini uygulamalarını gerçekleştirebilecekleri bir şapel kurmuş, bunu çocuklar için dekore etmiş ve uygulamaları yürütmesi için bir rahip görevlendirmiştir (Montessori, 1965'ten akt., Berryman, 2013a, s. 38). Dua etmek ve ayin düzenlemek gibi birçok din eğitimi uygulamasını kendi kurduğu bu okulda gerçekleştiren Montessori’nin yaklaşımları ölümünden sonra daha da geliştirilerek okuldaki din eğitimi uygulamalarına sistematik bir şekilde aktarılmıştır.

Maria Montessori hem çocuklar üzerinde gerçekleştirdiği uygulamalar hem de öğretmen eğitimleri kapsamında verdiği kurslardan yola çıkarak din eğitimi konusunda bazı kitaplar hazırlamıştır. 1929'da The Child in the Church, 
1931'de The Life in Christ, 1932'de The Mass Explained to Children adl1 kitapları yayımlanmıştır (Kramer, 1983, s. 329). Ancak Montessori'nin din eğitimi konusundaki uygulamalarının daha sistematik hale getirilip uygulamaya kavuşmas1, kendisinden sonra, onun üçüncü ve dördüncü nesil yorumcuları tarafindan gerçekleşmiştir. Üçüncü nesil Montessori yorumcularından Sofia Cavalletti (1917-2011) ve dördüncü nesil yorumcularından Jerome W. Berryman eğitim metodolojisi bakımından doğrudan Montessori geleneğine dayanan din eğitimi yaklaşımlarını geliştirmişlerdir (Berryman, 2013a, s. 38).

$\mathrm{Bu}$ makalede, Montessori'nin din eğitimi konusunda gerçekleştirdiği çalışmalar ile Berryman'ın O'nun eğitim ve din eğitimi teori ve uygulamalarından yola çıkarak geliştirdiği din eğitimi yaklaşımı incelenecektir. Bu çerçevede erken çocukluk ve çocukluk dönemi din eğitiminin genel eğitim ile bütünleşik bir şekilde gerçekleştirilme imkânı bu alanda yapılan bilimsel çalışmalar ışığında tartışlacaktır.

\section{Montessori ve Din Eğitimi}

Maria Montessori İtalyan bir doktor ve eğitimcidir. 1910'da kendisini tamamen eğitim konularına adamış ve bu tarihten itibaren çocukların eğitimi ile ilgilenmiştir. 20. Yüzyılın ilk yarısında Avrupa' da yaşanan siyasi ve ideolojik gelişmeler sebebiyle birçok ülkeye göç etmek zorunda kalmıştır.

1907'de Roma'da çocukların eğitimi amacıyla bir okul açan Montessori, başlangıçta engelli çocuklara dönük çalışmalarını daha sonra tüm çocukların eğitimine uyarlayarak bu konuda bir çığır açmıştır. Montessori çocukların özellikle doğuştan sahip olduğu bazı özellikler ve yeterliliklere vurgu yapmış, buradan hareketle eğitim yaklaşımını sistematikleştiren bazı uygulamalar geliştirmiştir. Montessori bu yaklaşımı 'kozmik eğitim' kavramıyla temellendirir. Ona göre bu yaklaşım insana empoze edilen bir ideal olarak sunulmak yerine, sürekli gelişme halinde olan içkin bir hakikat olarak sunulmalıdır. Çünkü insanın bir ideali zorla kabul etmesi düşünülemez. Bu bakımdan ideal bir eğitimin, insanın kendisinde doğuştan var olan bir gerçekliğe ve bu gerçekliğin yüceltilmesine göre düzenlenmesi gerekir (Montessori, 1991, s. 61'den akt., Cavalletti, 2000, s. 33).

Montessori’nin eğitime yüklediği anlam bazı olguların dışarıdan çocuğa aktarılması veya çocuğun bunları olduğu gibi almasına dayanan klasik yaklaşımın tamamen dışındadır. Montessori 1916 Noel arifesindeki ayinden sonra yakın arkadaşı Anna Maccheroni'ye şu ifadeleri kullanır: "Beni anlamayan birçok kişi, 
beni sadece çocukları izleyen, onları öpen, onlara peri masalları anlatan duygusal bir romantik zannediyor. Bunlar beni bezdiriyor. Ben Rousseau gibi bir idealist değil, titiz bir bilim muhakkikiyim. Çocuktaki adamı keşfetmeyi, ondaki gerçek insani ruhu görmeyi, yaratıcının tasarımını görmeyi isteyen kişiyim. $\mathrm{Bu}$ da bilimsel ve dini hakikattir. Benim çocuğa herhangi bir şey öğretmeye ihtiyacım yoktur. Uygun bir çevredeki çocuk, ruhu deforme olmadığı sürece, bana birçok şey öğretir ve manevi gizemini bana yansıtır.” (Kramer, 1983, s. 251).

Montessori'nin bakış açısında çocuk eğitimi çocukların uygun bir çevrede kendilerini ifade etmelerine dayanır. Çünkü çocuklar gerçek doğalarını uygun bir ortam içerisinde sergilerler. Bu koşullarda her çocuk düzene eğilimli, derin konsantrasyon, öz denetimli ve öğrenme isteklisi olarak gelişir. Montessori'de çocuklar bu alan içerisinde bir özgürlüğe sahiptir. Bu özgürlük çocuğun her istediğini istediği zaman yapması değil, bir seçim yapması ve seçilen aktiviteye odaklanmasıdır. Çocuğun seçimleri ise yapılandırıcı aktiviteler ve materyaller arasında gerçekleşir. Kısacası çocuğun öğrenmesi yetişkinin dayatması ile değil, hazırlanmış bir öğrenme ortamındaki kişisel keşiflerle gerçekleşir (Berryman, 2002, s. 99).

Montessori'nin eğitim anlayışında oyundan ziyade çalışma temel kavramlardan biri olarak karşımıza çıkar. Onun terminolojisinde çalışma çocuğun belirli bir faaliyet içerisinde bulunması anlamına gelir. Ona göre oyun çocuğun sadece belirli yönlerini geliştirirken çalı̧̧ma, onun bütün benliğinin derinliklerine iner. Çünkü çocuklar çalışırken hem ritim tutar hem de tekrar ederler. Bir çalışmanın bitmesini istemedikleri gibi bütün varlıklarını çalışmada sergilemeye çalışırlar. Kısaca çocuklar çalışmayı sever, çalışmayı yaşar, çalışırken eğlenir, çalışma aracılığı ile kendisini mükemmelleştirir (Standing, 1957, s. 130-138). Montessori'nin yaklaşımında çalışma, bir çocuğun kendisini ifade etmesinin en önemli aracı olarak görülmektedir. Çalışma çocukların geliştirdikleri spontane aktiviteler ile gerçekleşir. Montessori kendi rolünü maskenin ardındaki çocuğu keşfetmek için dikkatli gözlemler gerçekleştirmek ve çocuğun keşfedici yönünü açığa çıkarmak olarak açıklar (Berryman, 1980, s. 296). Buradaki gözlem, çocuğun fiziksel özelliklerinin ölçülmesi, aile görüşmeleri, çocuğun yoğunlaşma düzeyi, materyalleri kullanma düzeyi, çocuğun gerçekleştirdiği spontane hareketler gibi çok yönlü eğitim tekniklerine dayanır. Bu yöntem ve teknikler sayesinde öğretmen çocuğun neyi bilmek istediğini ve onunla nasıl iletişim kurulması gerektiğini öğrenir. Bunun için çocuğun yeteneklerine göre hazırlanmış doğal bir eğitim ortamına ihtiyaç vardır. Bu ortamda nesneler, semboller, dekor 
gibi çocuğu geliştirici birçok unsur yer almaktadır. Böylesi bir ortamda, çocuk kazandırılmak istenen davranışları, teorik olmaktan ziyade, geniş ve çeşitli deneyimler aracılığıyla öğrenir.

Çocuklar için hazırlanmış çevre, aynı zamanda onlara belli bir alan içerisinde özgürlükler sunar. Bu ortam içerisinde öğretmenin müdahalesi sınırlıdır ve sadece müdahale etmesi zorunlu olan durumlar için söz konusudur. Çocuklar bariz bir yanlış davranışta bulunmadığı sürece öğretmen müdahale etmez. Ancak müdahale grup içerisinde oyun tarzında olmalı ve çocuğun kendi hatasının farkına varması sağlanmalıdır. Montessori yaklaşımında ödül ve cezanın belirgin bir yeri yoktur. Ona göre eğitimde ödül veya ceza öğretici tarafindan uygulanan etkili yöntemler arasında değildir. Asıl ödül bir şeylere dâhil olmanın mutluluğu, asıl ceza ise bir şeyden mahrum kalmanın üzüntüsü olmalıdır (Schmid, 1970, s. 172).

Montessori İtalya'da karşılaştığı bazı problemlerden dolayı 1916 yılında en önemli takipçilerinden Anna Maccheroni’nin girişimi ile uzun süre kalacağ Barselona'ya yerleşir. Kaynaklarda Montessori’nin bu döneme kadar doğrudan din eğitimi ile ilgili bir çalışmasına rastlanmamaktadır. Bununla birlikte 1910 yılında akademik pozisyonlarından istifa edip, yakın arkadaşları ile birlikte Katolik kilisesine bağlı kalacağına ve hayatlarını çocuklara hizmet etmeye adayacaklarına dair bir yemin ettikleri bilgisine rastlyyoruz (Berryman, 2013a, s. 34). Ancak yaklaşık 20 yıl kaldığı Barselona'da Montessori, kendi eğitim yaklaşımını uygulama konusunda birçok çalışma yapmış, din eğitimi konusundaki fikirlerini daha ziyade burada geliştirmiştir. Montessori'nin bu çalışmalar kapsamında kendine özgü müfredatlar geliştirdiği ve bu konuda öğretmenlere din eğitimi konusunda bazı seminerler verdiği bilinmektedir. Bu anlamda Barselona okulu onun din eğitimi yaklaşımı konusunda bizlere birinci elden veriler sağlamaktadır.

Montessori'nin din eğitimine olan ilgisinin temelinde onun çocukta doğal olarak var olduğuna inandığı dini bir hissin (religious sentiment) mevcudiyeti konusundaki düşüncesi yer alır. Ona göre bu hissin geliştirilmesi ve din eğitiminin bu argüman üzerinden temellendirilmesi gerekir. İnsanların bu histen yoksun bırakılması onların ruhsal gelişimini olumsuz etkiler. Bu sebeple dini hissin insan yaşamındaki doğal yerinin korunması ve geliştirilmesi gerekmektedir (Berryman, 1980, s. 301). Bunun yanında öğretmenlerin bu konuda özel bir eğitim almaları da zorunludur. Çünkü Montessori'nin yaklaşımının önemli bileşenlerinden biri de çocukların manevi eğitimleri sırasında yetişkinlerin 
rehberliğine duyduğu ihtiyaçtır. Bu eğitim mutlaka bir yetişkin rehberliğinde yapılmalıdır (Berryman, 2013a, s. 18). Montessori bunun bir seçenek ya da tercih durumu olmadığını, aksine bir gereklilik olduğunu belirtir. Çünkü ona göre din eğitimi, çocukların eğitimine dahil edilmediğinde iki problemin belirmesi muhtemeldir: Ahlaki yaşantıda denge kaybı ve dini fanatizm. Montessori'ye (1912, s. 373) göre dini fanatizm, maneviyattan mahrum kalan bir hayatın doğal sonucudur.

Montessori'nin din eğitimi uygulamalarını gerçekleştirdiği Barselona'daki okulun bulunduğu ortam aslında çocuğun doğa ile iç içe olduğu bir eğitim ortamıdır. Montessori'nin biyografisini hazırlayan Rita Kramer, buradaki okulu şöylece tasvir etmektedir: Okul ferah zemini, bahçeleri, meyveliği, palmiyelerle uzayan yollarıyla geleneksel İspanyol mimarisini temsil eden eski bir yapı idi. Bahçesi çeşmeler, kulübeler, hayvanlar için barınaklar ile donatılmıştı (Kramer, 1983, s. 250). Okulun bulunduğu yerleşkenin bizim için asıl önemli yönü, okulun içerisinde din eğitimi açısından oldukça önemli kabul edilen bir şapelin yapılmış olmasıdır.

Eğitim ortamında bir şapelin varlığı ve bu şapelin özellikle çocukların dini eğitimi açısından düzenlenmiş olması Montessori’nin eğitim ve doğallık arayışının açık bir göstergesidir. Çünkü onun din eğitimi uygulamaları semboller, simgeler ve kavramların yaratıcı kullanımlarından hareket etmekte, hatta bunların daha da ötesine geçmektedir (Berryman, 1980, s. 306). Montessori'nin din eğitimi anlayışında okul ve kilisenin bir arada bulunduğu, başka bir deyişle ikisinin de mevcut konumlarından çıkarak daha doğal bir öğrenme ortamına dönüştüğü bir mekân arayışının varlığı göze çarpmaktadır. Buradan hareketle Montessori'nin çocukların dini yaşantıyı deneyimleyebilecekleri ve inancın derin gerçekliğini hissedebilecekleri bir mekân tasarladığı anlaş1lıyor (Stonehouse, 2006, s. 174). Montessori çocuğun din eğitiminin gerçekleştirileceği mekânı 'atrium' kavramıyla ifade eder. Bu düzenleme çocuğun öğrenme ortamının özel olarak bir mekânda sürdürülmesi anlamına gelir. Montessori aslında bu düzenlemeyi kilise ile sınıf arasında ara bir mekân olarak planlamıştır. Ancak burası ne akademik bilgi verme yeri ne de dini öğretim yapma mekânıdır. Burası her şeyden önce dini yaşamın sergilendiği bir ortamdır. Burası aynı zamanda çocuğun çalışacağı bir ortamdır ve Tanrı ile girilen bir sohbetin özel bir mekânıdır (Cavalletti, 1992, s. 56).

Montessori öğrenme ortamının kendi eğitim anlayışına göre düzenlenmesi için mekânın tasarımı, özellikle de okul içerisinde bulunan şapelin iç mima- 
risiyle özel olarak ilgilenmiş, bu çerçevede bazı yerel sanatçılar ile görüşmüş, bu görüşmeler ışığında şapelin içini bazı heykel, resim ve bir dizi materyallerle donatmıştır. Burada dini anlamı olan birçok materyal çocukların kullanabilmesi için küçültülmüştür. Bu düzenlemelerin amacı çocukların günlük hayatlarında gerçekleştirdikleri birçok doğal ve sıradan etkinliği okulda da gerçekleştirebilmelerine imkân sağlamaktır. Bunların başında dua ve bazı ayinlerin yapılması gelmektedir. Burada çocuklar özellikle dua sırasında, birçok somut nesneyi kullanmakta daha da önemlisi, böylesi doğal bir ortamda aynı hissiyatı yaşayan çocuklarla birlikte deneyimlerini paylaşmaktadır (Schmid, 1970, s. 22). Buradan hareketle Montessori’nin duayı din eğitiminin temel bir konusu olarak gördüğü söylenebilir.

Barselona okulunda gerçekleştirilen din eğitiminin amacı çocuğa dini bilgi aktarmanın ötesinde günlük yaşamla ilgili doğrudan deneyimler sunmaktır. $\mathrm{Bu}$ amaçla okulda çocukların hem din eğitimi konusundaki faaliyetlerini planlamak hem de bu konu ile ilgili etkinliklerini gözlemlemek üzere bir rahip görevlendirilmiştir. Genç rahibin görevi dua ve bazı ayinler için gerekli hazırlıkları yapmaktır. Örneğin rahibin yapacağı faaliyetlerden biri, bazı Hıristiyan ayinleri için önceden gerekli eğitim ortamını hazırlamaktır. Ancak bu hazırlıklar bazen uzun bir sürece yayılabilir. Çünkü bir ayin için kullanılan her şeyi çocuklar bizzat kendileri hazırlarlar. Örneğin ekmek yapmak için gerekli buğdayı okulun bahçesinde yetiştirirler. Ekilen buğday olgunlaştı̆̆ında bunu toplayıp renkli şeritlerle bağlarlar ve un yapmak için hazır hale getirirler. Ardından bunlar hamur haline getirilir ve her çocuk için hazırlanmış bir sembol ile işaretlenerek ekmek yapılır. Ayin için kullanılacak şarap da okulda yetiştirilen üzümden hazırlanır. Bu üzümü çocuklar kendileri toplarlar. Bu çerçevede gerçekleştirilen faaliyetler din eğitiminin önemli bir yönünü oluşturur ve günlük hayatın olağan bir parçası haline getirilir (Montessori, 1965 'ten akt., Berryman, 2013a, s. 38).

Montessori'nin bizzat kendisinin gerçekleştirdiği bu uygulamalardan yola çıkarak onun din eğitimi ile ilgili iki temel ilkeden hareket ettiğini söyleyebiliriz. Birinci ilke iyi bir eğitim ortamının Tanrıyı sevme ve onu tanımaya firsat vermesidir. Çünkü yedili yaşlara kadar birbirlerini seven ve tanıyan insanlar, Tanrı'yı sevme ve tanıma konusunda bir altyapı kazanmış olurlar (Montessori, 1949, s. 413). İkinci ilke ise Tanrı'nın varlığını çevremizdeki birçok doğal olgudaki sembolizmde görebilme imkânıdır. Bir ağacın büyümesi, bitkilerin yeşermesi, bir tohum, ortak yapılan eylemler veya bir masanın etrafında oturup birlikte yemek yeme gibi birçok sembol Tanrı'yı anlatmanın en iyi yoludur (Schmid, 1970, s. 170). 
Montessori'nin Barselona'daki tecrübelerini yansıtan en önemli eseri The Child in the Church'tür. Bu eser ilk olarak Montessori tarafindan 1922'de Napoli'de 52 sayfalık bir kitapçık şeklinde yayımlanmış (I bambini viventi nella Chiesa-The Children Living in the Church), Standing 1929'da bu kitapçığın 191 sayfalık daha geniş versiyonunu hazırlamıştır. Eser nihayet 1965 'te de son ve en kapsamlı biçimiyle yayımlanmıştır (Kramer, 1983, s. 328). Kitabın 1965 baskısı Montessori'nin metninin yanında onun yorumcularının katkılarını da içeren bölümle birlikte 224 sayfaya ulaşmıştır (Berryman, 2002, s. 98). Yine Montessori henüz hayatta iken 1931'de The Life in Christ, 1932'de ise The Mass Explained to Children yayımlanmıştır (Kramer, 1983, s.329). Montessori'nin çocuğun din eğitimi ile ilgili görüşlerini, sistematik olmasa da, genel anlamda bütün bu eserlerinden çıkarmak mümkündür.

Montessori yaklaşık 20 yıl kaldığı Barselona'dan İspanya'daki iç savaştan dolayı ayrılarak 5. Uluslararası Montessori Kongresi için İngiltere'ye gider. Burada daha ziyade Londra'daki bazı okullardaki din eğitimi konuları ile ilgilenir. Mother Isabel Eugenia'nın isteği ile 1936'da Assumption College'de din eğitimi üzerine dersler verir. The Child in the Church kitabının 1965 baskısındaki resimlere bakılırsa, Londra'daki St. Anthony's School'daki okul müfredatı ve materyaller açısından burada da özel bir eğitim ortamı oluşturulduğu anlaşı1maktadır. Aynı şekilde İskoçya'nın Glasgow şehrinde de bu yaklaşımı benimseyen bir okul açılmış ve 300 çocuğun eğitim görmesi sağlanmıştır. Sözü edilen kitapta bu okulun resimleri de mevcuttur (Berryman, 2002, s. 101).

Montessori yorumcularından Cavalletti, Montessori'nin kendi kullandığı din eğitimi örneklerinden yola çıarak şu değerlendirmelerde bulunmaktadır: Çocukların dindarlığı o kadar güçlüdür ki olumsuz çevre koşullarından kolay kolay etkilenmemektedir (Cavalletti, 1992, s.32). Çevre sadece çocuğa uygun bir ortam sunmakla kalmayıp çocuğun dini gelişimine de önemli katkılar sağlamaktadır.

Montessori’nin ölümünden sonra onun din eğitimi yaklaşımı üçüncü nesil yorumcularından Sofia Cavalletti ve dördüncü nesil yorumcularından Jerome W. Berryman tarafindan yeniden yorumlanarak sürdürülmüsstür. Cavalletti, The Good Shepperd yaklaşımı ile katı bir şekilde Montessori yaklaşımına bağlı kalmış ve sözü edilen erken çocukluk dönemi din eğitimi yaklaşımını geliştirmiştir. Montesssori geleneğini sürdürme konusundaki en önemli katkıların Cavaletti'den geldiği söylenebilir. Cavalletti, bu alana üç noktada katkı sağlamıştır: İlk olarak daha düzenli bir din eğitimi müfredatını yaygınlaştırmış, ikinci olarak bu yaklaşımı yaygınlaştıracak uluslararası organizasyonlar geliştirmiş, üçüncü ola- 
rak da bu yaklaşımın metodolojisi için teolojik bir temel sağlamıştır. Berryman ise hem Montessori hem de Cavalletti'nin yaklaşımlarından hareketle Godly Play adını verdiği erken çocuklukta din eğitimi modelini geliştirmiştir.

\section{Berryman'ın Erken Çocukluk Din Eğitimi Yaklaşımı: Godly Play}

Godly Play ${ }^{19}$ erken çocukluk ${ }^{20}$ ve çocukluk dönemi için hazırlanmış ve Hıristiyanlık esaslarına göre düzenlenmiş bir sınıf ortamında Hıristiyan din dili sistemini kullanarak hayatın amaç ve anlamını keşfetmede uzmanlaşmayı amaçlayan bir din eğitimi yaklaşımıdır (Grajczonek ve Truasheim, 2017, s. 174). Bu yaklaşım Montessori yorumcularından Jerome W. Berryman tarafindan pedagojik olarak Montessori ve Cavalletti'nin görüşlerine, teolojik olarak da Paul Tillich ve Samuel Terrein'in yorumlarına dayanmaktadır. Bu yaklaşımın temel felsefesini ise kutsal metinlerdeki herhangi bir anlatımın oldukça küçük çocukların dünyasına hitap eden bir yönünün olduğu, bunun uygun eğitim yaklaşımları ile iyi bir rehberliğe dönüştürülebileceği anlayışı oluşturur.

Yaklaşım din dili sistemini kullanma ve çocuklarda manevi deneyimler geliştirmek için, varoluşsal problemlerin üstesinden gelmede Yaratıcı ile ilişki geliştirmek hususunda çocuklara ortam hazırlama ve firsat yaratmayı amaçlamaktadir (Berryman, 1985, s. 125). Bunu da Montessori yöntemine uygun bir sınıf ortamında, kutsal metinler, kutsal anlatımlar, kıssalar, ayinsel faaliyetler gibi din dili sistemini edindirmeyi sağlayan araçlar ile gerçekleştirmeyi hedefler (Hyde, 2010, s. 507). Bu yaklaşımın ana çerçevesini Kutsal metinlerdeki anlatımlar aracılığı ile Hıristiyan yaşam tarzını göstermek, yaşatmak ve şekillendirmek oluşturur (Berryman, 2013a, s. 120).

Berryman, söz konusu eğitimci ve teologlardan etkilenmesinin yanı sıra kendisi de tıpkı Montessori gibi uzun süre hasta çocuklarla ilgili uygulamalı çalışmalar gerçekleştirmiştir. Özellikle de 1972'de İtalya'da Montessori Araştırmaları Merkezi'nde (Bergamo) sertifika almakla kalmamış aynı zamanda burada Montessori'nin din eğitimi ile ilgili uygulamalarından çok etkilenmiştir. Burada Montessori'nin din eğitimi anlayışını aynen sürdüren Cavalletti ile tanışan Berryman, Montessori'nin eğitim anlayışı ile ilgili şu değerlendirmelerde bulun-

19Bazı İngilizce ifadelerin Türkçe çevirileri kavramın ifade ettiği temel mantığ1 yansıtmadığı için yapılmamıştır. Godly Play ifadesi de bu sebeple çevrilmemiştir. Tanrısal oyun şeklinde Türkçeye çevrilebilecek bu kavramın, yaklaşımın özünü yansıtmadığı görülmüştür. Bu sebeple İngilizce ifade aynen korunmuştur.

20Erken çocukluk, early childhood ifadesinin Türkçe çevirisidir. Piaget'nin işlem-öncesi dönemine karşılık gelir ve yaklaşık olarak 2-7 yaş dönemi için kullanılır. 7 yaşından itibaren çocukluk dönemi başlar (Bkz., Santrock, 2009, s. 217) 
maktadır: 'Nasıl bir din eğitimi yapılması gerektiği ile ilgili hayalini kurduğum şeyin Montessori'nin bizzat kendisi tarafindan anlaşılmaya başlandığını gördüm.' (Berryman, 1985, s.124; 1991, s. 26; Hyde, 2011a, s. 342).

Berryman, İtalya'da hem Montessori eğitim anlayışını incelemiş hem de bu anlayışı din eğitimine uygulayan Cavalletti ile tanışarak ilerleyen yıllarda iyi bir meslektaş dayanışması gerçekleştirmiş̧ir. 1973'te Amerika'ya döndükten sonra Montessori anlayışına göre eğitim veren bazı okullar ile diğer okullarda dersler vermiştir. $\mathrm{Bu}$ süre içerisinde kendine özgü bir din eğitimi yaklaşımını geliştirmeye ve uygulamaya çalışmıştır (Hyde, 2013a, s. 3-4). Bu konudaki çalışmalarını 1991'de Godly Play adlı çalışmasıyla somutlaştırmış ve bunun yanında birçok uluslararası çalışmaların içerisinde bulunmuştur (Hyde, 2013a, s. 5). Günümüzde bu din eğitimi yaklaşımı başta $A B D$ ve Avusturalya olmak üzere, Meksika, Kanada, İngiltere, İskoçya, İspanya, Finlandiya, Almanya ve Kenya gibi birçok ülkede uygulanmaktadır (Hyde, 2011a, s. 341).

\section{Yaklaşımın Temelleri}

Goldy Play, Montessori'nin de ifade ettiği üzere çocukta doğal bir maneviyatın varlı̆̆ını kabul eder ve bu temel tez üzerinden hareket eder. Söz konusu manevi yetenekler rehberlik edilmediği takdirde eksik ve işlenmemiş olarak kalır (Hyde, 2013a, s. 11). Montessori'ye (1912, s. 373) göre bu yeteneklerin geliştirilmemesi ilerleyen yıllarda radikalizme yol açar. Buradan hareketle Berryman (2013a, s. 1), çocukların, henüz resmi bir din eğitimi pratiğinden geçmeden önce, manevi deneyimlere sahip olduğunu ifade eder. Bu deneyimlerin sergilenmesi ve manevi gelişimin tamamlanabilmesi için uygun bir ortama ve rehberliğe ihtiyaç vardır (Ratcliff ve Ratcliff, 2010, s. 20).

Montessori kendisinden önce eğitim tarihinde uzun süre kabul gören ve çocuğun eksik bir varlık olduğu, geleceğin yetişkini olması için tamamlanması gerektiği şeklindeki 'boş bir levha' yaklaşımına karşı çıkar (Kramer, 1983, s. 251). Berryman, çocukların boş kaplar olarak görülmesi ve yetişkinler tarafından bazı doktrinler ile doldurulması şeklindeki yaklaşımın tamamen dışında, Montessori'nin belirtmiş olduğu çerçevede bir din eğitiminin mümkün olduğunu belirtir. Ona göre çocuğun ihtiyaç duyduğu şey, onların zihinlerini bazı bilgi veya varsayımlarla doldurmak değil, aksine kendi Tanrı deneyimlerini tanımlama ve yansıtma için uygun bir dili kullanmayı öğretmektir (Hyde, 2013a, s. 2).

Berryman'a göre Hıristiyan din dili sisteminin birçok yönü vardır. Bunları sistematik olarak, kimlik kazanma (kutsal hikâyeler), Hiristiyan olmanın anla- 
mını keşfetme (kıssalar), Hıristiyan toplumunun davranışlarına katılma (ayinsel hareketler), Tanrının gizemini doğrudan deneyimlemenin yollarını açma şeklinde özetlemek mümkündür (Hyde, 2013a, s. 2). Bütün bu süreçler hem pedagoji hem psikoloji hem de teolojinin verilerini kullanarak çocuğun kazanımlarına dönüştürülür. Bu yaklaşımın pedagojik temelinin Montessori’nin eğitim anlay1şına dayandığını belirtmiştik. Şimdi bu yaklaşımın psikolojik ve teolojik temellerini sirasiyla inceleyelim.

Godly Play'in psikolojik temellerinde özellikle oyun konusunda, Mihaly Csikszentmihalyi ve Donald W. Winnicott'un (1896-1971) yaklaşımlarının kullanıldığı görülmektedir (Berryman, 2009, s. 239). Psikiyatr Winnicott öğrenmelerimizin önemli bir kısmını oluşturan 'geçiş alanı' (transitional space) şeklinde isimlendirdiği bir alandan bahseder. Burada 'geçiş objeleri' sayesinde insan bilinç durumunun dışında, fakat hayat boyunca zihninde yer eden birçok nesneyi hatırlar ve bunları yaşar. İnsan bunlarla yaşamaktan rahatsız olmaz, üstelik bunları hayatı boyunca da unutmaz. Özellikle geçiş döneminde örneğin bebek ve çocukların en sevdikleri battaniye veya oyuncaklar hatırlanamayabilir; ancak bu tür nesnelerin hatırası canlı bir şekilde yaşar ve bunların hatırası yetişkinlikte de devam eder (Berryman, 2013a, s. 92). Winnicott'un bu ayrımından hareket edildiğinde, dini bir sembol veya simgenin, kutsalı hatırlatan herhangi bir nesnenin doğrudan bir geçiş objesi olması mümkündür. Bütün bu nesneler çocukta kutsallığın temellerini oluşturur (Otto, 1958, s. 112).

Godly Play'in sınıf ortamındaki çeşitli materyaller, Winnicott'un belirttiği geçiş nesneleri fonksiyonu şeklinde düşünülmüş ve Otto'nun kutsallığı açığa çıkarışı ve geliştirici süreçleri ile uyumlu olarak yer almıştır. Godly Play sınıflarına giren bir insan, rafların somut eğitim materyalleri ile dolu olduğunu görür. Ancak bunlar sadece somut materyaller olarak görülemez. Çünkü bunlar Montessori'nin ifadesiyle 'duyusal materyaller'dir. Bu tür eğitim objeleri düşünceye dalma ile ruhu bilme ve akılla zihni bilmenin yanı sıra duyuları bilerek Hiristiyan dilinin imkânlarını öğrenmeyi sağlar. Bu materyallerin etkili olabilmesi için öğretmenin bunları geçiş objesi haline getirmesi gerekmektedir (Berryman, 2013a, s. 93).

Godly Play'in oyun konusundaki psikolojik temeli geçiş nesneleri ayrımına dayanmaktadır. Ancak bunun dişında gelişim psikolojisi konusunda Piaget ve Erikson'un kuramlarına da müracaat edilmektedir. Özellikle çocukların potansiyel olarak neleri yapabilecekleri konusunda sözü edilen psikologların görüşlerinden faydalanılmıştır. Ancak bu kuramların da bazı açılardan farklı prob- 
lemler taşıdığı belirtilir. Bu kuramlara yapılan en temel eleştiri gelişimin belli bir noktadan başlayıp belli bir doğrultuda ilerleyerek zirveye ulaşması tezine dayanan, çizgisel bir gelişim anlayışıdır. Bu yaklaşımın aksine Godly Play'de gelişimin karmaşık bir niteliğe sahip olduğu ve maneviyat gibi bazı yeterliliklerin erken yaştan itibaren gelişme gösterdiği varsayılır (Hyde, 2013a, s. 9).

Godly Play'in teolojik temellerini ise Samuel Terrein, Paul Tillich ve Paul Ricoeur gibi teolog ve yorumbilimcilerin görüşleri teşkil eder. Berryman bu konuda Hıristiyanlığın Katolik yorumunu benimseyen Montessori ve Cavalletti'den farklı olarak Hıristiyanlığın Protestan yorumunu benimser. Yine teolojik olarak çocuğun kutsallıkla ilişkili (sacrament) bir varlık olarak görülmesi temel ayrışma konularından biri olarak karşımıza çıkar. Berryman ayrıca eğitim süreçlerinde ayinlerden ziyade Tanrı'nın Kelamı üzerinde yoğunlaşır. Bu bakışın bir sonucu olarak çocuğun manevi gerçekliğe dil ve semboller aracilığıyla ulaşacağ1 düşünülür (O'Shea, 2018, s. 310-312). Bu konuda ayrıca çalışmalar yapmak mümkündür. Ancak biz burada kısaca bu yaklaşıma temel teşkil eden yönleriyle sözkonusu görüşlere kısaca yer vereceğiz.

Godly Play 'Tanrı'nın deneyimlenebileceği' teolojik kabulünden hareket eder. $\mathrm{Bu}$ herhangi bir yorumla veya anlatımla olabilecek bir durum değildir. Buna göre çocuklar Tanrı'yı dışarıdan kendilerine aktarılan bilgilerle değil, kendi günlük yaşamlarındaki deneyimlerle yaşar ve keşfederler (Berryman, 2013a, s. 82). Çocuklar zaten manevi varlıklar oldukları için, kendi benlikleri, diğer insanlar, doğa ve Tanrı ile ilişkiyi kendiliğinden kurarlar. Onlar bilginin ve varlığın uç noktalarında yaşarlar ve onların kendi yaşamlarının varoluşsal sınırları ile ilgili derin kaygıları vardır. Çocukların maneviyatı sözel olmadığı için, ihtiyaç duydukları şey Tanrı ile ilişkiyi ifade edecek bir dile sahip olmamalarıdır. İşte din eğitimi esas olarak bu dili kazandırmayı hedefler (Hyde, 2013b, s. 143).

Berryman din dilini halihazırda çevremizde deneyimlediğimiz dilin ötesinde, kişinin kendi varlığının ve kendilik bilgisinin sınırlarında varoluşsal dünya ile ilişkilendirir (Berryman, 1992, s. 21). Godly Play'ın en önemli kavramlarından biri de işte bu varoluşsal sınırlardır. Bunlar: ölümle ilgili kişisel deneyimler, topluluk içerisindeki yalnızlık hissi, anlam arayışı, insan özgürlüğünün ne anlama geldiği ile ilgili tutumlar olarak sıralanabilir. Söz konusu varoluşsal meseleler yetişkinler için olduğu kadar çocuklar için de bir problem teşkil eder. Çocuklar bütün bu meseleleri, yetişkinler kadar olmasa da, kendi dünyalarında deneyimler ve kendilerine özgü bir dille ifade ederler (Berryman, 1995, s. 38). Yaklaşımın ölüm ve varoluşsal meseleler konusunda, varoluşsal psikoterapinin 
etkilerini -özellikle de Irvin D. Yalom'un çalışmalarını- görmek mümkündür (Schwartz, 2019).

Godly Play bu temellerden hareketle Huristiyan bir din dili sisteminin kutsal hikayeler, İncil kıssaları ve ayinsel ifadeler ile küçük çocuklara belli bir metodoloji eşliğinde anlatılabileceğini kabul eder. Bütün bu süreçler Tanrı'nın deneyimlenmesinde hayal gücünü geliştirme, düşünceye sevketme, Winnicott'un bahsettiği şekliyle geçiş objeleri aracılığıyla oyuna dönüştürme gibi bir metodoloji kullanmayı gerektirir. Berryman'a göre bazı ilkeler gözetildiği takdirde, çocuklar varoluşsal meselelerle baş edecek şekilde, maneviyatlarını ve varoluşlarını ifade edecek din dili sistemini kazanırlar.

İlk olarak din dilinin şekillenmesi yazılan ve konuşulan dilin ötesinde çocukların duyusal olarak kullanabilecekleri özel bir dile dönüşmesi ile mümkündür. Bu durum kutsal metinlerdeki anlatımları basitleştirmek değil, aksine kıssaları, kutsal anlatıları ve ayinsel hareketleri çocukların ilgilenebileceği somut formlar haline getirmektir. Bir çocuk kendisine önceden sunulmuş reçeteler yerine sınıfta kendisine anlatılan kıssaların bazı somut formlarını yanıbaşında bulabilmeli ve onlarla ilgili bir yönlendirme olmaksızın, bireysel yahut grupla birlikte bunlarla ilgilenmeli, bunlar üzerine konuşabilmelidir. Bu nesneler bir geçiş objesi olarak çocuğun manevi yaşantısını ve Tanrı deneyimini kolaylaştırır ve bu deneyimi kendine özgü sözcüklerle ifade etmesini sağlar.

İkinci olarak çocuklara sunulan din dili sistemi belli aralıklarla çocukların bu konuda önceden hazırlanmış materyallerle vakit geçirmesine izin vermelidir. Din dili, öğretim sürecinde varsayılan şeylerin yapılması konusunda her şeyden önce bazı pratikler gerçekleştirmelidir. Bunlar Tanrı'yı bilme ve deneyimleme konusundaki temel kaynaklardır, kutsal anılar paylaşılır, nesilden nesile aktarılır, Tanrı ile ilgili bilgi sağlamaya teşvik edilir, kimlik şekillendirilir, insan davranışlarına anlam kazandırılır (Stewart ve Berryman, 1989, s. 24). Ancak Godly Play'in teolojik yorumunda kıssa veya kutsal anlatımlar çocuğun dünyasına bir amaç olarak sunulamaz. Aksine bunlar kişinin kendi bireysel hikâyesinin kutsal metinlerdekiler ile buluşması ve çocuğun hayatında kendisine yardım eden, yol gösteren araçlar olarak sunulmalıdır. Kısaca kutsal metinlerdeki anlatımlar bir amaç değil günlük hayatın yol göstericileridir.

Üçüncü olarak çocuklar kutsal metinlerdeki anlatımlara bazı sanat formlarında yanıt vermeye ihtiyaç duyarlar. Bunlar hayal gücünü geliştirmede çocuğa önemli bir imkân sağlar. Ricoeur'un ifadesiyle hayal gücü insanı gerçekliğin en derinlerine ulaştıran yaratıcı süreçlerden biridir (Berryman, 2013c, s. 191). 
Böylece çocuklar semboller dünyasındaki araçlar sayesinde din dilinin bir sentezine ulaşabilirler. Kıssadaki anlatımın canlandırılması, resmedilmesi veya başka bir sanat formunda ifade edilmesi hem yaratıcılığı ortaya çıkarır hem de maneviyatın gelişimini destekler.

Son olarak çocukların herhangi bir anlatıma verdikleri sanatsal yanıtlar, onlarda merak duygusunu geliştirir. Bu aşamada çocuklar verilen yanıtlardan hareketle farklı yorumlar çıkarma ve sentezlerde bulunma firsatı yakalayabilir. (Berryman, 2001, s. 9; 2013b, s. 306; 2013d, s. 201-202). Cavalletti'nin (1992, s.138) ifadesi ile 'Çocuklar merak işaretleri ile gelişir.' Bunun için çocuklara sürekli bir şekilde merak soruları yöneltmek yöntem olarak benimsenmiştir. Bu bakımdan kıssa yahut herhangi bir dini anlatımda çocuğun merakını uyandırabilecek konular başlangıç düzeyindeki sorularla çocuğa yöneltilir ve çocuğun bunları kendisinin yapılandırması beklenir (Stewart ve Berryman, 1989, s. 31). Bu sorular hem kıssadaki anlatım ile ilişkili, hem de çocuğun günlük yaşamı ile de doğrudan ilişkili olmalıdır.

\section{Yaklaşımın Amaçları}

Berryman'a göre din eğitiminin amacı hem çocukların hem de yetişkinlerin içtenlikle Tanrı'yı bilmeleri ve bunu varoluşsal mesele olarak anlam dünyalarına dâhil etmeleridir. Bunun için, din dili de kullanılarak, insanın kendi sınırlarını zorlaması ve kendisiyle yüz yüze gelmesi gerekir. Bu bakımdan Montessori yaklaşımına uygun olarak hazırlanmış bir çevrede, çocukların doğal ortamlarında oldukça erken yaşlardan itibaren din eğitiminin gerçekleştirilebileceği varsayılır. Berryman, Montessori’nin Barselona okulunda yaptığını daha sistematik hale getirir ve din eğitimi için en uygun mekânın ne kilise ne de klasik bir sınıf ortamı olduğunu belirtir. Ona göre Hıristiyan din dili sistemini öğrenmenin ideal ortamı, hem kiliseden hem de sınıftan bazı izlerin olduğu eğitim ortamı olmalıdır. Bu ortam kiliseden bazı izler taşımakla birlikte Montessori yaklaşımına göre düzenlenmiş bir sınıf ortamı olmalıdır. Böyle bir ortamda kişi gerçek yaşam deneyimleri ile dini deneyimler arasında ortak bir bağ kurarak dini deneyimi hayatın içinde sergiler (Berryman, 1991, s.7).

Godly Play yaklaşımı din eğitimi konusunda temel bazı hedefler belirlemiştir. Bunları şöylece sıralamak mümkündür:

Din eğitiminde çocuğun merak duygusunu geliştirmek için model oluşturmak. Çocukların çok meraklı varlıklar olduğu açıktır. Ancak onların merakını 
yönlendirmek ve onları meraka değer konulara yöneltmek için rehberlik etmek gerekir. Özellikle dini konulara yöneltilen ilgiler sayesinde, çocuklar salt bir tekrar veya bir konu hakkında konuşmanın ötesinde, din diline dâhil olurlar.

Çocukların Tanrıyı deneyimlemelerine yardım etmek. Çocuklar Hıristiyan geleneğinin diline nasıl dahil olacağı ve bunu hayatlarına nasıl aktaracağı konusunda özellikle desteklenmelidir. Bunun için gerekli hazırlıkların yapılması ve bazı araçların temin edilmesi gerekir.

Çocukların kendi çalışmalarını desteklemek. Çocuklar din eğitimi sınıflarında kendi çalışmalarını seçmeye ihtiyaç duyarlar. Yetişkinlerin problemlerinden ziyade çocukların kendi problemleri ile ilgili konulara yönelecekleri bir sınıf ortamı onlara yeterli motivasyonu sağlayacaktır. Çocuklar bu türden etkinliklerle varoluşsal sınırlarını aşmaya başlar ve ilgilerini bazı konular üzerinde yoğunlaştırmaya gayret ederler.

Bir topluluk içerisinde hareket etmek. Çocuklar din eğitimi sınıflarında birbirilerine ve birbirilerinin çalışmalarına saygı duyarak ve destekleyerek birlikte çalışmaya ihtiyaç duyarlar. Başta dua olmak üzere bireysel olarak gerçekleştirilen bazı uygulamaları topluluk olarak gerçekleştirmek din eğitiminin en önemli yöntemlerinden biridir. Burada bir topluluk içerisinde Tanrı ile olmanın en iyi yolu olan toplu duadır. Böylece dinin sosyal boyutlarını bir bütün olarak toplum içerisinde yaşama ve hayata geçirme imkânı bulur (Berryman, 1995, s. 17; 1991, s.60).

\section{Yaklaşımın Uygulama Süreci}

Godly Play, sınıf ortamında birçok Hıristiyan uygulamasını temsiller aracıllı̆ı ile sunar. Herhangi bir eğitim kurumunda -kreş, anaokulu veya ilkokul- bir s1nıf Montessori ve Berryman'ın belirttikleri şekilde hazırlanır. Bu sınıf sadece Godly Play yaklaşımı için kullanılır. Sınıfın zemini öğrencilerin ayakkabılarını çıkarıp yere oturabilmeleri için halı ile kaplanmıştır. Sınıf öğrencilerin kendi seçimlerini yapabileceği uygulamalara müsait bir şekilde düzenlenir. Sınıfta öğrencilerin daire oluşturarak oturmalarını temsil eden bir işaret, Hıristiyan kıssaları ve semboller sistemini temsil eden materyaller raflara düzenli bir şekilde yerleştirilmiştir. Sınıfın duvarları Hıristiyan semboller sistemi ile döşenmiştir. Öğrencilerin dersten sonra serbest etkinlikler ve sanatsal faaliyetleri gerçekleştirebilecekleri küçük masa ve sandalyeler, kıssaları ifade etmede kullanılabilecek oyun hamurları, farklı renklerde kalemler, resim çalışmaları için ma- 
teryaller bulunur. Kısaca sınıf ortamı kiliseye ait bazı temsillerin yer bulduğu, bununla birlikte eğitim-öğretim unsurlarının daha baskın olduğu bir şekilde düzenlenmiştir.

Öğrenciler sınıflara kalabalık gruplar halinde alınmazlar. Genelde 5-10 öğrenci birlikte sınıfa alınır ve eğitim kurumundaki her öğrencinin haftada bir kez bu sınıfa gelmesi beklenir. Godly Play sınıflarının öğrenci ve öğrenme ortamı dışında iki önemli unsuru vardır. Bunlardan ilki, çocukları kapıda karşılayarak içeri girme konusunda hazır olup olmadıklarını soran, ders bittikten sonra çocukların sınıfta kendi başlarına gerçekleştirecekleri çalışmalarda çocukların 'kendilerine yardım etmelerine' yardım eden, çocuklara ikramları hazırlamada yardım eden, dersin sonunda sınıftaki işleri biten çocukları isimleri ile çağıran ve dışarıda bekleyen velilere çocukların çalışmaları ile ilgili bilgi veren yardımcı öğretmendir. Bu öğretmen doorperson diye adlandırılır (Berryman, 1995, s. 23). İkincisi ise derste sunulacak materyalleri kontrol eden, daire oluşturulacak mekâna geçerek öğrencileri bekleyen, gelen çocukların uygun şekilde yerleşmelerine yardım eden, dersin sunumunu gerçekleştiren, ders esnasında çocukların kıssanın ruhuna dâhil olmaları için model oluşturan, çocukların serbest vakitlerinde çalışmalarını gözlemleyen, ikramdan sonra çocuklarla birlikte şükran ifadeleri kullanan, dersin sonunda çocukları birer birer karşısına alıp iyi insanlar olmalarını telkin edip onları takdis eden, çocukları uğurlayan ve çocuklar çıktıktan sonra da, kıssa ile ilgili materyalleri kontrol eden öğretmendir (Berryman, 1991, s. 93).

Godly Play yaklaşımında öğretmenin iyi bir teolog veya eğitim uzmanı olmasına gerek yoktur. Öğretmenin çocuklarla iletişim kurabilmesi için iyi bir gözlemci olması, daha da önemlisi Tanrı'nın insana olan sevgisinin gizemini anlamaya çalışarak saygıyla ve tevazuyla çocuğun yanı başında durabilmesi en önemli yeterlilik olarak görülmektedir (Schmid, 1970, s. 45; Hyde, 2011b, s. 25). Bunun dışında Montessori yaklaşımının en önemli öğretmen yeterliliği olarak gördüğü öz sayg1 da burada özellikle vurgulanır. Hatta bu yaklaşımda öğretmenin öz saygısı onun çocuklara olan saygısı kadar önemli kabul edilir (Berryman,1980, s. 298).

Godly Play yaklaşımı ilk dönemlerde daha uzun bir sürede gerçekleştirilmesine rağmen son dönemlerde yaklaşık 20 dakika ile sınırlandırılmıştır. Bu süre zarfında çocuklar grup halinde veya bireysel olarak bazı etkinlikler gerçekleştirir. Bu etkinlikler gelişigüzel bir şekilde değil Hıristiyanlık ayinlerinin (Holy Eucharist gibi) bir temsilini yansıtacak şekilde düzenlenmiştir. Bu süreçleri şöylece özetleyebiliriz: 
Öğrenciyi selamlama. Yardımcı öğretmen kapıda bekleyerek her bir öğrenciyi selamlar ve onların içeri girmeleri konusunda hazır olup olmadığını sorar. Kapıda durma, çocukların bir yetişkin tarafından karşılanması ve hazır olduklarında çocukların içeri alınması, İsa ile ilgili bir anlatıma dayanmaktadır. Çünkü İsa kendisini derin gerçekliğe giden yolda bir kapı şeklinde nitelendirmiştir (Berryman, 1995, s. 21). Bu sebeple öğrencilerin Tanrının kelamını işitecekleri özel bir mekâna girdiklerini hissetmeleri ve hazır olduklarını söylediklerinde de öğretmenin bulunduğu yerdeki daireye dâhil olmaları istenmektedir.

Tanrı'nın kelamını işitme. Öğrenciler öğretmenin çevresinde daire oluştururlar ve öğretmen her bir öğrenci ile kısa bir konuşma yaptıktan sonra en son anlatılan kıssayı hatırlatır ve o günün kıssası ile ilgili ipuçları verir. Öğretmen her davranışında öğrencilerin merak duygusunu harekete geçirecek cümleler kurar. Anlatılacak kıssanın materyallerinin bulunduğu kutuyu açarak öğrencilerin bunları merak etmesini ve anlamlandırmasını ister. Öğretmen aslında kıssayı hikâye anlatır gibi anlatmaz. Çünkü bu yaklaşımda en etkili öğrenmenin bir şeyler hakkında konuşmak değil, göstererek yapılan uygulamaların olduğu varsayımından hareket edilir (Berryman, 1995, s. 43). Öğretmen bütün çocukların ortasına materyalleri dizer ve kıssanın özünü temsil eden noktaları materyaller eşliğinde sadece gösterir. Böylece çocuklara kıssanın özünden hareketle bunu kendi yaşamları ile ilişkilendirecekleri bir bakış açısı kazandırılmaya çalışılır. $\mathrm{Bu}$ yaklaşımda kıssalar; düşünülmeyeni deneyimleme konusunda çocuklara yardım eder, kültürel sınırlar olmaksızın hayata anlam vermede duyarlılık kazandırır, varoluşsal bir yaşam deneyimi sağlar ve daha da önemlisi kıssalar eğitime dâhil edilerek çocuklarda merak duygusu doğal olarak geliştirilir (Berryman, 1995, s. 39). Asıl amacı kıssa anlatmak olmamakla birlikte, öğretmen kıssaları bu bakış açısı ile sunmalı ve hedefinin anlatılardan hareketle çocuğun dünyasına nüfuz etmek olduğunu bilmelidir.

Derse yanıt verme. Öğretmen sunulan kıssa hakkında ne hissetmeleri ve düşünmeleri gerektiği konusunda çocuklara herhangi bir şey söylemez. Çünkü böyle bir müdahale çocukların kendi yorumlarından vazgeçmeleri ile sonuçlanabilir. Burada temel bakış açısı 'yaparak' öğrenmedir, aksine çocuğa dışarıdan bir şeyler anlatmak değildir (Berryman, 1995, s. 37). Bu süreçte öğretmen çocuklara kendilerine gösterilen kıssadan ne anladıklarını sorar ve bunun günlük hayatlarında nasıl bir yerinin olabileceğine dair cevaplar vermesini ister. Ancak çocuğun bu soruları cevaplayabileceği bir süreyi vermekten de geri kalmaz. Öğretmen kıssanın ana mesajı ile ilgili sorular yöneltir ve bu çerçevede çocuk- 
lardan kıssadan ne anladıklarını ifade etmelerine destek olur. Genelde beş-altı öğrenci ile ders yapıldığı için her öğrenciye kendisini ifade etme firsatı verilir.

Merak uyandırma. Çocuğun derse yanıt vermesi ve kıssaya daha derinden dâhil olmasında merak uyandırma, bu yaklaşımın en önemli yönlerinden biri olarak görülmektedir. Öğretmen çocuğun kıssayı anlaması ve kendi hayatı ile ilişkilendirmesi noktasında bazı merak soruları ile çocukları yanıt vermeye çağırır. "Kıssanın en çok hangi bölümünü sevdiğini merak ediyorum", "Kıssanın en çok hangi bölümünü önemli gördüğünü merak ediyorum" gibi yönlendirmelerle çocukların kendilerini ifade etmesi sağlanır (Grajczonek ve Truasheim, 2017, s.175). Bazen de sadece 'Ben merak ediyorum ki...' şeklinde bir ifade ile öğrencinin cümlenin kalan kısmını tamamlaması beklenir. Ancak burada önemli olan nokta çocukların cevaplarının yargılanmaması ve değerlendirilmemesidir. Çocuğun kıssadan edindiklerine öğretmenin saygı duyması gerekir. Burada çocukların öğretmenin sözlerini aynen tekrarlamaları veya benzer ifadeleri kullanmalarından kaçınmak gerekir. Bu her ne kadar birçok öğretmenin hoşuna gitse de bu yaklaşımın amacı değildir (Berryman, 1995, s. 38).

Serbest çalı̧̧ma. Merak sürecinden sonra çocuklar anlatılan kıssaya verecekleri cevaplar konusunda düşünmeye davet edilir. Bu bazen bir canlandırma bazen de bir resim yapma şeklinde olabilir. Bu aşamada çocuklar sınıfta serbest faaliyetlerde bulunurlar. İsteyen öğrenciler bir takım sanatsal faaliyetleri gerçekleştirir; örneğin kıssanın ruhuna uygun resimler yapar, isteyen öğrenciler de sınıfta Hıristiyan din dili sistemine ait sembol ve simgelerin bulunduğu raflara yönelir, önceki derslerde anlatılan kıssaların materyallerini incelerler. Bu süreçte yardımcı öğretmen de çocuklara rehberlik eder.

İkram hazırlama ve paylaşma. Ders bittikten sonra yardımcı öğretmen bazı öğrencilerle birlikte ikramlık hazırlar. Genelde bisküvi ve meyve suyu olan ikramlıkları öğretmenin çevresinde oturan öğrencilere yine öğrenciler dağıtır. Böylece çocukların birlikte yaşamayı ve paylaşmayı öğrenmeleri teşvik edilir. Çocukların ikramlarını yemeleri de yine İsa'nın havarileri geçirdiği ve Hıristiyanlıkta önemli kabul edilen ayinlerin bir sembolü olarak değerlendirilmektedir. Ayrıca öğretmenin bütün çocuklarla birlikte geçirdiği bu vakit ‘öğretilebilir anlar' yakalamak açısından önemli kabul edilir. Çocuklarla birlikte gerçekleştirilen bu ortak faaliyetler, her ne kadar ders dışı faaliyetler olarak görünmekle birlikte derse dahildir ve Hıristiyan din dili sistemini kazanma açısından öğretilebilir anlar yakalama firsatı sunar (Berryman, 1995, s. 77). Çocuklar ikramı bitirdiklerinde sınıflardan ayrılma vakti gelmiştir ve o günkü dersin amacına ulaştığ 1 varsayılır. 
Kutsama ve uğurlama. Öğretmen öğrencileri isimleri ile sırasıyla karşısına çağırarak onlar için dua eder. Bireysel olarak her öğrenci öğretmenin karşısına geçer ve kutsandıktan sonra yardımcı öğretmenin gözetiminde sınıftan çıkar (Berryman, 1991, s. 45, 87;1995, s. 82).

\section{Değerlendirme}

Montessori ve Cavalletti'nin geliştirdiği din eğitimi yaklaşımını erken çocukluk ve çocukluk dönemi din eğitimine uyarlayan Berryman kutsal metinlerdeki anlatıların çocukların günlük yaşamları ile ilişkilendirilmesi fikrinden hareketle Godly Play adını verdiği yeni bir eğitim yaklaşımı geliştirir. Kutsal anlatılar, kıssalar, semboller, simgeler ve ayinsel uygulamalar aracıllı̆ı ile Hıristiyan din dili sistemini kazandırarak Tanrı ile canlı bir ilişki geliştirmek ve bunu sürdürmek bu yaklaşımın en önemli amacıdır (Hyde, 1990, s. 123). Bunları sağlamak için entelektüel anlamda bir din eğitimine, uzman bir din eğitimcisine veya eğitim uzmanına ihtiyaç yoktur. Bunu sağlamak için, iyi gözlem yapan bir öğretmenin gözetiminde uygun materyallerle hazırlanmış uygun bir sınıf ortamı yeterlidir. Godly Play yaklaşımının uygulaması ve karşılaşılan problemler konusunda yapılmış çok fazla çalışma yoktur. ${ }^{21}$ Yapılan çalışmalardan hareketle bu yaklaşıma yönelik bazı eleştirileri kısaca değerlendirmek istiyoruz.

Çocukların geçiş nesneleri şeklinde oyun pedagojisi ile ilişkili olarak sınırlı süre zarfında söz konusu kazanımları elde etmesi mümkün müdür? Erken çocuklukta herhangi bir etkinlikte bireysel ve grup çalışmalarına çocukların dâhil olmaları için geniş vakitlere ihtiyaç vardır. Bu tür keşfetme faaliyetlerinin sınırlı zamanlarda sınırlı materyallerle gerçekleştirilmesi pedagojik olarak bir sınırlandırılmışlığa işaret eder. Eğer oyun veya diğer etkinlikler belirli bir durum ile sınırlandırılırsa bu sınırlılık kısa sürede aynı şeylerin tekrarına düşme ve dolayısıyla pasifleştirici bir sürece dönüşme riski taşımaktadır (Grajczonek ve Truasheim, 2017, s. 182). Godly Play yaklaşımında çocukların geçiş nesneleri ile oyun ortamında vakit geçirmeleri oldukça sınırlıdır. Bu sebeple özellikle kıssa anlatımından sonra çocukların yaklaşık beş dakika süren serbest vakitte oyun için gerekli vaktinin olmadığı görülmektedir.

Yaklaşımın en önemli kabul ettiği yönlerden biri de çocuklarda merak hissini geliştirmek için 'öğretilebilir anlar' yakalamaktır. Berryman, yaklaşımın en önemli amaçlarından birinin çocuklarda din diline yönelik bir merak uyandırmak olduğunu belirtir. Bunun için de ders sürecinde öğretmen merak ifadelerini

21 Ülkemizde erken çocukluk dönemi din eğitimi konusunda son dönemlerde akademik bir ilgi gelişmiş durumdadır. Bu konuda kapsamlı bir karşılaştırmalı çalışma için Tosun ve Yıldız’a (2019) bakılabilir. 
sıklıkla kullanır. Hatta bu sınıfta kullanılacak bazı soruların kalıpları da geliştirilmiştir. Ancak bu soruların da belirli ve sınırlı bir zaman diliminde çocuklarda merak duygusunu geliştirip geliştirmeyeceği tartışma konusudur.

$\mathrm{Bu}$ yaklaşımda sınıf pedagojisinin bir gereği olarak uygulanan 'merak soruları'nın zoraki ve yapay durduğu şeklinde bir değerlendirme vardır (Grajczonek ve Truasheim, 2017, s. 181). Bu değerlendirme çocukların herhangi bir konuya ilgi göstermediği durumlar için geçerli olabilir. Ancak Godly Play yaklaşımının sınıflar için seçtiği kıssalar ve her bir kıssa ile ilgili materyaller çocukların birinci derecede ilgisini çekecek bir şekilde düzenlenmiştir. Aksine 'şunu merak ediyorum' şeklinde öğrencilerin verdikleri açık uçlu yanıtlar, çocukların kıssanın tamamını keşfetmede hayal gücünü geliştirmek için önemli bir fırsat sağlar. Bu sayede çocuklar bir metindeki ifadeler yerine metnin anlamına dâhil olurlar. Godly Play'da çocuğun kıssadan anladığı şeyler dışında ayrıca bilgi verilmediği için çocukların kendi anlayışlarını geliştirmesi teşvik edilmektedir (Grajczonek ve Truasheim, 2017, s. 172).

Diğer bir eleştiri ise bu yaklaşımın aynı dine inanan insanların oluşturduğu bir topluluk için geliştirildiğinden, okul öncesi veya temel eğitim kurumlarında uygulanamayacağı hususudur. Başka araştırmalarda bunun haklı bir eleştiri olmadığı, söz konusu yaklaşımın hem okul öncesi hem de okul çağı çocuklar1 için uygulanabileceği, bazı ön hazırlıklar yapıldığı takdirde öğretmenlerin ve anne babaların bunu uygulayabilecekleri belirtilmiştir (Ratcliff ve Ratcliff, 2010, s. 56). Ancak bu açıklamalar Godly Play yaklaşımının farklı din mensubu ailelerin çocuklarının bulunduğu sınıf ortamında uygulanması problemine yeterli bir yanıt oluşturmamaktadır. Çünkü Elkind'in (1970) çalışması özellikle erken çocukluk ve çocukluk döneminde diğer dinlerin öğretilmesi konusunda bazı ipuçları vermektedir. Bu yaş dönemindeki çocuklar, aile ve yakın çevrenin inancını anlama sürecindedirler ve diğer dini inanışları anlamaya yönelik hazırbulunuşluk düzeyine ulaşmamışlardır. Bu sebeple bu yaklaşımın çok kültürlü ve çok dinli sınıflarda uygulanması bazı dini gelişim problemlerine yol açabilir. Yaklaşımın aynı din mensubu çocuklar için uygulanabileceği söylenebilir.

Öğretmenin rolü konusundaki bir diğer eleştiri ise Godly Play'in bir öğretmenin yapması gerekenler konusunda eksik kaldığı eleştirisidir. Bir öğretmenin planlamadaki etkisi, bazı başarı kriterleri geliştirme, öğrenci başarısı ile ilgili veriler toplama, bütün öğrencilerden geri bildirim alma, öğrencilerin kendi öğrenmelerini sahiplenmeleri için onları harekete geçirme gibi noktalarda öğretmenin kendi rollerini yerine getiremediği belirtilmektedir (Grajczonek ve Tru- 
asheim, 2017, s. 183). Montessori yaklaşımında olduğu gibi Godly Play'de de öğretmenin rolü geleneksel öğretmenin rollerinden farklıdır. Öğretmenin iyi bir gözlemci olması ve bu gözlemler sayesinde çocuklarla iletişim kurabilmesi en temel öğretme yeterliliği olarak görülmektedir (Stonehouse 2006, s. 187). Ayrıca bu yaklaşımda öğretmenin iyi bir teolog veya eğitim uzmanı olması da gerekli görülmemiştir (Schmid, 1970, s. 45; Hyde, 2011b, s. 25). Görüldügü kadarıyla Godly Play'de öğretmenin rolü iyi bir gözlem yapabilme ve öğrencilerde merak uyandırmadır. Ancak sadece bunların yapılabilmesi bile öğretmenliğin temel becerilerini gerektirir. Öğretmenlik sadece gözlem yapma ve merak uyandırmadan ibaret değildir. Gelişim psikolojisi araştırmalarına göre öğretmenlik için alan bilgisi ve pedagojik yeterlilikler temel ölçüt olarak belirtilir (Slavin, 2006, s. 3, 5). Bu ölçütler okul öncesi öğretmenliğinden yüksek öğrenime kadar bütün eğitim süreçlerini kapsamaktadır. Bu sebeple, erken çocukluk ve çocukluk dönemi din eğitimi ögretmenlerinin hem ilahiyat hem de eğitim bilimleri ve pedagojik formasyon alanlarında uzmanlaşmış olması gerekmektedir.

Godly Play'a yönelik bu eleştirilerin yanında, yaklaşımın çocuk maneviyatına önemli bir katk1 sağladığı sonucuna ulaşan çalışmalar da mevcuttur. Örneğin çocuk maneviyatı konusunda önemli çalışmaları bulunan Catherine Stonehouse, Godly Play sınıfları ile bu eğitime katılmamış çocuklar üzerinde gerçekleştirdiği araştırmasında bazı değişkenler açısından bir karşılaştırma yapmıştır. $\mathrm{Bu}$ çalışmaya göre Godly Play sınıflarındaki çocuklar açık bir şekilde diğer çocuklardan manevi gelişim açısından daha yüksek puanlar elde etmişlerdir (Stonehouse, 2001, s. 38).

Stonehouse'un çalışmasında çocukların kıssaları somut materyaller ile öğrenmeleri ve her hafta bunları görmelerinin önemli bir gelişim sebebi olduğu görülmüştür. Araştırmacı diğer grup çocuklar için genel bazı resimler ve İncil anlatımları kullanmış, çocukların da bu tür anlatımlara aşina olmamalarından dolayı bazı zorluklar yaşadığını gözlemlemiştir. Godly Play yaklaşımının anlatılan kıssalara yaratıcı bir şekilde dahil olmaları ve oradaki anlamı keşfetmeleri konusunda çocuklara yardım ettiği açık bir şekilde görülmüştür. Bazı çocukların iki yada üç yıl bu yaklaşım çerçevesinde eğitim aldıkları, kıssalara oldukça aşina oldukları, buradaki materyalleri kullandıkları ve bu kıssaları günlük hayatlarında ve özellikle dualarında kullandıkları görülmüştür. Çocukların kıssa anlatımı konusunda da oldukça istekli oldukları gözlenmiştir.

Bu araştırmada Godly Play sınıflarındaki çocukların yaklaşık \%35'inin kıssalar ve Tanrı konusunda merak geliştirdikleri görülmüştür. Aynı araştırma sonuç 
olarak Godly Play'in çocuklara kıssaları dinleme ve onları yansıtma konusunda gerekli yer ve zaman sağladığını belirtir. Aynı şekilde bu okulda eğitim gören çocukların kıssaların anlamlarını merak etme, materyaller ile ilgilenme, kendi başlarına bu kıssalar ve materyaller ile çalışma, düşüncelerini ifade etme ve kıssanın anlamını keşfetme konularında da istekli oldukları görülmüştür (Stonehouse, 2001, s. 39, 41, 44).

Brendan Hyde'nin gerçekleştirdiği uygulamalı araştırmada ise, Godly Play sınıflarındaki çocukların 'manevi arayış' konusunda aktif bir katılımcı oldukları gözlemlenmiş̧ir. Çocukların bu derslerden sonra hayatın anlamı ve amacı konusunda bir arayış içerisinde oldukları görülmüş ve bu arayışta çocuklar için neyin önemli ve değerli olduğu konusunda bazı düşüncelerin geliştiği tespit edilmiştir (Hyde, 2010, s. 515).

Hyde'nin değerlendirmesine göre kıssanın içeriği ile uyumlu bir şekilde gözlem yapan çocuk ortak bir yaratıcı faaliyette buluşmuştur. Bu da Godly Play'in en önemli amaçlarından biridir. Hyde'nin çalışması Godly Play'in özellikle iki açıdan çocuklara önemli destekler sağladığını göstermiştir: Bunlardan ilki çocukların önceki derslerde ele alınan kıssalara ait materyaller ile ilgilenmelerine firsat verilmektir. Böylece çocukların geçmişte öğrendiği konular ile bir bütünlük kurmaları sağlanarak onların manevi gelişimi desteklenmektedir. İkinci olarak ise, çocukların kullanılan kıssayı sadece içselleştirmediği aynı zamanda Hıristiyan din dili sistemini geliştirmek için kullandığı da görülmüştür. Burada özellikle çocukların kıssa anlatımı esnasında kullanılan dilin aynısını kullandıkları, böylece çocukların anlatılan olaya dâhil oldukları görülmüştür (Hyde, 2010, s. 516).

\section{Sonuç}

Sonuç olarak Godly Play pedagojik, psikolojik ve teolojik temelli bir din eğitimi yaklaşımı olarak yeterli sürenin olmaması, öğrenciyi merkeze alması, bazı kazanımları edinme konusunda yetersiz kalması bakımından eleştirilse de bu konuda yapılan farklı çalışmalarda bu yaklaşımın genel olarak başarılı bir din eğitimi uygulaması olduğunu ifade etmektedir. Hıristiyan din dili sistemini aktarması açısından özellikle sınıf ortamının buna uygun bir şekilde düzenlenmesi, kutsal metinlerdeki kıssa ve anlatımların bazı somut sembol ve simgeler aracılığı ile aktarılması, öğrencilerle birebir ilgilenebilecek bir sınıf ortamının oluşturulması, çocuk maneviyatı açısından ileri sayılabilecek bir durumdur. 
Goldy Play doğrudan Hıristiyanlığı benimsetmeye dönük bir eğitim yaklaşımıdır. Sınıftaki bütün uygulamalar Hıristiyanlıktan izler taşır ve eğitimin her bir aşamasında Hıristiyan din dili sisteminin bir yönünü görmek mümkündür. $\mathrm{Bu}$ yaklaşımın din eğitimi ve öğretimi açısından diğer dinlere uyarlanması da mümkündür. Ancak bu konuda bazı ilkelerin göz önünde bulundurulması gerekir. Bu ilkelere kısaca bakacak olursak;

(A) Seçilecek klssaların içeriği. Erken çocukluk din eğitiminde kutsal metinlerdeki her kıssa veya anlatı kullanılamaz. Burada çocukların gelişim düzeyleri dikkate alınarak bir seçim yapmak gerekir. Ayrıca seçilen kıssanın bütün içeriklerinin de anlatılmasına gerek yoktur. Çünkü erken çocukluk dönemi, sistematik bir din eğitiminden ziyade bir ilgi uyandırma dönemidir. Bunun için de Godly Play yaklaşımında olduğu gibi çocukların merak duygularını geliştirecek ve canlı tutacak kıssalar tercih edilmelidir. Yine seçilen kıssaların çocukların günlük yaşamlarında bir karşılığının olması, dolayısıyla din ile günlük yaşam arasında bağ kurulabilecek bir içerik ve yöntemin seçilmesi gerekir.

(B) Materyallerin Seçimi: Kıssaların veya bazı dini simgelerin somut materyaller olarak hazırlanması, dini her konunun somutlaştırılabileceği anlamına gelmez. Çünkü küçük çocuklara dini öğretmek adına her türlü dini kavramı somutlaştırmak antropomorfik düşünce şeklini ön plana çıkarır ki bu özellikle İslam dini açısından bir problem teşkil eder. Bu sebeple materyalleri hazırlanacak kıssalar antropomorfizmi destekleyen unsurları değil, günlük yaşama dair unsurları içermelidir.

(C) Sinıf düzeni. Montessori yaklaşımına göre bir sınıf düzeninin, öğrencilerin kendi seçimlerini yapmaları, bu seçimler çerçevesinde etkinlikler gerçekleştirmeleri, görevlilerin desteğini alabilmeleri gibi konularda bir özgürlük alanı bırakması gerekmektedir. Bu düzenlemelerle çocuğun kendisini ayrı ve özel bir yerde olduğunu hissetmesi sağlanmalıdır. Godly Play yaklaşımı bu problemi pedagoji ve teolojiden bazı unsurları sınıf ortamına aktarmakla çözmüştür. Genel eğitim ortamında bir sınıfın sadece din eğitimi için ayrılması, dekore edilmesi, dini sembol ve simgelerle donatılması ve sınıfın Montessori eğitim yaklaşımına göre düzenlenmesi çocukta dolaylı öğrenmeyi destekler. Böyle bir sınıf düzenlemesi eğitim ile günlük yaşam ilişkisini kurmada doğal bir ortam sağlar.

(D) Öğretmen tutumu. Erken çocukluk din eğitimi yaklaşımlarının çocuklarda doğuştan bir kutsallık hissi veya manevi yönelim olduğunu kabul ettiğini belirtmiştik. Bu ön kabulden hareketle çocukların uygun bir çevrede maneviyatlarını açığa çıkaracağı varsayılmaktadır. Bu sebeple öğretmen bir inanç sistemini öğreten, çocukların dini konularda nasıl düşünmesi gerektiğini anlatan biri değil, 
materyaller eşliğinde gösterilen kıssadan çocukların ne anladığını açığa çıkaran rehberdir. Bu sayede öğrencinin sahip olduğu manevi özü, kutsal metinlerdeki anlatımlar ile buluşturması ve bunu geliştirmesi beklenmektedir. Böylece öğretmen bu keşfetme sürecinde çocuğun manevi gelişimine rehberlik eder.

\section{Kaynakça}

Berryman, J. W. (1980). Montessori and religious education. Religious Education, 45(3), 294-307.

Berryman, J. W. (1985). Children's spirituality and religious education. British Journal of Religious Education, 7(3), 120-127.

Berryman, J. W. (1991). Godly Play-A way of religious education. New York: HarperCollins Publishers.

Berryman, J. W. (1992). Faith development and the language of faith, In D. Ratcliff (Ed.) Handbook of Children's Religious Education. Birmingham: Religious Education Press.

Berryman, J. W. (1995). Teaching godly play-the Sunday morning handbook. Nashville: Abingdon Press.

Berryman, J. W. (2001). The Nonverbal nature of spirituality and religious language, In J. Erricker, C. Ota ve C. Erricker (Ed.) Spiritual Education-Cultural, Religious and Social Differences New Perspectives for the $21^{\text {st }}$ Century. Brighton: Sussex Academic Press.

Berryman, J. W. (2002). The Complete guide to godly play (1)-An imaginative method for presenting scripture stories to children. USA: The National Council of Churches of Christ.

Berryman, J. W. (2009). Children and the theologians-Clearing the way for grace. New York: Morehouse Publishing.

Berryman, J. W. (2013a). The Spiritual guidance of children-Montessori, godly play, and the future. New York: Morehouse Publishing.

Berryman, J. W. (2013b). Theologizing with children-A parable approach, In B. Hyde (Ed.) The Search for a Theology of Childhood-Essays by Jerome $W$. Berryman from 1978-2009 (s. 291-311). Ballarat: Modotti Press.

Berryman, J. W. (2013c). Imagination, In B. Hyde (Ed.) The Search for a Theology of Childhood-Essays by Jerome W. Berryman from 1978-2009, 191-194. Ballarat: Modotti Press.

Berryman, J. W. (2013d). Caring for sick children: The parish, the hospital and theological play, in B. Hyde (Ed.) The Search for a Theology of Childhood-Essays by Jerome W. Berryman from 1978-2009, 195-206. Ballarat: Modotti Press. 
Cavalletti, S. (1992). The religious potential of the child. (Translated by, P. M. Coulter ve J. M. Coulter), Chicago: Liturgy Training Publications.

Cavalletti, S. (2000). The religious potential of the child 6 to 12 years old. (Translated by, R. Rojcewicz \& A.R Perry), Chicago: Liturgy Training Publications.

Elkind, D. (1970). The origins of religion in the child. Review of Religious Research, 12(1), 35-42.

Grajczonek, J. ve Truasheim, M. (2017). Implementing godly play in educational settings: A cautionary tale. British Journal of Religious Education, 39(2), 172-186.

Hyde, B. (2010). Godly play nourishing children's spirituality: A case study. Religious Education, 105(5), 504-518.

Hyde, B. (2011a). Montessori and Jerome W. Berryman: Work, play, religious education, and the art of using the Christian language system. British Journal of Religious Education, 33(3), 341-353.

Hyde, B. (2011b). Berryman and the purpose of religious education: The significance of Berryman's approach to religious education for Catholic schools. Journal of Catholic School Studies, 83(1), 20-28.

Hyde, B. (2013a). Teaching the Christians' strange language: Berryman, religious education and spirituality, In B. Hyde (Ed.) The Search for a Theology of Childhood-Essays by Jerome W. Berryman from 1978-2009. Ballarat: Modotti Press.

Hyde B. (2013b). Preface to part three, In B. Hyde (Ed.) The Search for a Theology of Childhood-Essays by Jerome W. Berryman from 1978-2009, 143-144. Ballarat: Modotti Press.

Hyde, K. E. (1990). Religion in childhood \& adolescence. Birmingham: Religious Education Press.

Kramer, R. (1983). Maria Montessori-A biography. Chicago: University of Chicago Press.

Montessori, M. (1912). The Montessori method. (translated by, Anne E. George), New York: Frederick A. Stokes Company.

Montessori, M. (1949). The Absorbent mind. India: The Theosophical Publishing House.

Montessori, M. (1965). The Child in the church. (edited by, E.M. Standing), St. Paul, MN: Catechetical Guild.

O'Shea, G. (2018). A comparison of catechesis of the good shepherd and godly play. British Journal of Religious Education, 40(3), 308-316. 
Otto, R. (1958). The Idea of the holy. (translated by, John W. Harvey), London: Oxford University Press.

Ratcliff, D. ve Ratcliff, B. (2010). ChildFaith-experiencing God and spiritual growth with your children. Oregon: Cascade Books.

Santrock, J.W. (2009). Life-span development. Boston: McGraw-Hill Companies.

Schmid, J. (1970). Religion, Montessori, and the home-an approach to the religious education of the young child. New York: Benziger Inc.

Schwartz, V. (2019). The theological differences between godly play and catechesis of the good shepherd. Erişim adresi: (06 Nisan 2019) https://cctheo.org/occasional-papers

Slavin, R. E. (2006). Educational psychology. Boston: Pearson.

Standing, E. M. (1957). Maria Montessori-Her life and work. California: Academy Library Guild.

Stewart, S. M. and Berryman, J. W. (1989). Young children and worship. Louisville: John Knox Press.

Stonehouse, C. (2001). Knowing God in childhood: A study of godly play and the spirituality of children. Christian Education Journal, (5)2, 27-45.

Stonehouse, C. (2006). Joining children on the spiritual journey-nurturing a life of faith. Michigan: BakerBooks.

Tosun, A. ve Yıldız, K. (2019). Erken çocukluk dönemi din eğitimi yaklaşımları üzerine karşılaştırmalı bir analiz. Amasya İlahiyat Dergisi, 12, 121-151. 
Extended Abstract

\section{Application of Montessori Educational Approach to Religious Education: The case of Godly Play}

Cemil ORUÇ, Corresponding Author, Assoc. Prof.

Inonu University, Faculty of Theology.

E-mail: cemil.oruc@inonu.edu.tr

ORCID: 0000-0002-9870-8597

\section{Introduction}

Maria Montessori (1870-1952), one of the most important actors of the twentieth century in education, focused on education. She pioneered many practices that could be considered quite advanced for her time on child education. Montessori also gave importance to religious education within the framework of her educational approach and carried out some practices in this regard. It is possible to see her approach on this subject in the practices he carried out in Barcelona school (Montessori, 1965; Berryman, 2013a, s. 38). Montessori's approaches, which carried out many religious education practices such as prayer and ritual at his own school, were further developed after her death and systematically transferred to religious education practices in the school. Based on Montessori tradition in terms of educational methodology, Jerome W. Berryman, fourth generation commentator, developed a religious education approach (Berryman, 2013a, s. 38). 


\section{Montessori and Religious Education}

At the heart of Montessori's interest in religious education it lays her thought of the existence of a religious sentiment which she believes naturally exists in the child. According to her, this feeling should be developed and religious education should be based on this argument. Deprivation of people from this feeling adversely affects their mental and spiritual development (Berryman, 1980, s. 301; 2013a, s. 18). Montessori states that this is not an option or a preference, but a requirement. According to her, two problems are likely to arise when religious education is not included in the education of children: Loss of balance in moral life and religious fanaticism. According to Montessori (1912, p. 373), religious fanaticism is the natural consequence of a life deprived from spirituality.

The existence of a chapel in the educational environment and the fact that this chapel is arranged especially for the religious education of children is a clear indication of Montessori's quest for education and naturalness. Her practices of religious education are based on the creative use of symbols and concepts and even go beyond these (Berryman, 1980, s. 306). In Montessori's understanding of religious education, there is a search for a place where school and church are together, in other words, both of which have evolved from their present positions into a more natural learning environment. From this point of view, it is understood that Montessori designed a place where children can experience religious life and feel the deep truth of faith (Stonehouse, 2006, s. 174). Montessori expresses the place of child's religious education with the concept of 'atrium'. This means that the child's learning environment is maintained in a particular space. Montessori originally planned this arrangement as a different environment between church and class. However, this is neither a place of academic information nor a place of religious instruction. First of all, this is an environment where religious life takes place. It is also a place for the child to work and a special place for a conversation with God (Cavalletti, 1992, s. 56).

The aim of religious education at the Barcelona school was to provide the child with direct experience of everyday life rather than giving religious knowledge (Montessori, 1965; Berryman, 2013a, s. 38). We can say that, based on these practices, Montessori himself developed two basic principles of religious education. The first principle is that a good educational environment allows loving and experiencing God. Until the age of seven, children who love and know each other have gained a basis for loving and knowing God (Montessori, 1949, s. 413). The second principle is the possibility of feeling God's existence 
in symbolism in many natural phenomena around us. Many symbols, such as the growth of a tree, the growth of plants are the best way of religious education (Schmid, 1970, s. 170; Berryman, 2002, s. 101).

\section{Berryman's Approach to Early Ghildhood Religious Education: Godly Play}

Godly Play is a religious education approach that aims to specialize in discovering the purpose and meaning of life by using the Christian language system in a classroom setting prepared for early childhood and childhood and arranged according to Christian principles (Grajczonek ve Truasheim, 2017, s. 174). This approach is based pedagogically on Montessori and Cavalletti's views and theologically on the comments of Paul Tillich and Samuel Terrein. The basic philosophy of this approach is that any narrative in the sacred texts has an aspect that appeals to the world of very young children and that it can be turned into good guidance through appropriate educational approaches (Berryman, 1985, s.124; 1991, s.26; Hyde, 2011a, s. 342).

\section{Foundation of the Approach}

Montessori states that every child has a natural spirituality. These spiritual abilities remain incomplete and inadequate unless guided (Hyde, 2013a, s. 11). According to Montessori (1912, p. 373), lack of development of these capabilities led to radicalism in later years. From this point of view, Berryman (2013a, p. 1) states that children have spiritual experiences before they go through a formal practice of religious education. Appropriate environment and guidance are needed to demonstrate these experiences and complete spiritual development (Hyde, 2013a, s. 2; Ratcliff and Ratcliff, 2010, s. 20; Kramer, 1983, s. 251).

According to Berryman, the Christian religious language system has many aspects. These can be summarized systematically as gaining identity, discovering the meaning of being Christian, participating in the behavior of Christian society and opening up the ways to experience the mystery of God directly (Hyde, 2013a, s. 2). With using pedagogy and theology, all these aspects can be an attainment.

\section{The purposes of the Approach}

Godly Play approach has set some purposes in religious education. These are as follows: To create a model to develop the child's sense of curiosity in religious 
education, to help children experience God, to support children's own work and to act in a community (Berryman, 1995, s. 17; 1991, s.60).

\section{Application Process of the Approach}

Godly Play offers a variety of Christian practices in classrooms through representations. In any educational institution -kindergarten or elementary school- a class is prepared according to the advices of Montessori and Berryman. This class is only used for Godly Play. Students are not admitted to classes in crowdw ed groups. In general, 5-10 students are admitted to the class together and each student is expected to come to this class once a week. The classroom environe ment has already been prepared in such a way that every student can do free studies on the story told to them. Courses are held in the following order: Greeting the student, hearing the word of God, responding to the lesson, arousing curiosity, working freely, preparing and sharing food.

\section{Evaluation and Conclusion}

Berryman, who adapted Montessori's educational approach to early childhood religious education, develops a new educational approach called Godly Play based on the idea that the narratives in the sacred texts are related to the daily lives of children. The most important purpose of this approach is to develop and maintain a lively relationship with God by acquiring the Christian religious language system through sacred narratives, parables, symbols and rituals (Hyde, 1990, s. 123).

In this approach, there is an assessment that 'curiosity questions' applied as requirements of class pedagogy are forced and artificial (Grajczonek and Truasheim, 2017, s. 181). This assessment can be accepted for situations where children are not interested in the topic. However, the stories chosen by Godly Play approach for the classes and the materials related to each story are arranged in ways that draw the attention of children (Grajczonek ve Truasheim, 2017, s. 172).

Another criticism is that this approach cannot be applied in pre-school or primary education institutions because it is developed for a community of people who believe in the same religion. However, it is stated in other studies that this is not a justified criticism and that this approach can be applied to both preschool and school age children, and if some preliminary preparations are made, teachers and parents can apply it (Ratcliff ve Ratcliff, 2010, s. 56). 
In addition to these criticisms of Godly Play, there are also studies that conclude that the approach has made a significant contribution to children's spirituality. Catherine Stonehouse, who has important studies on child spirituality, makes a comparison in terms of some variables in her research on Godly Play classes and children who have not attended this education. In this study, children in Godly Play classes clearly scored higher scores in terms of spiritual development than other children (Stonehouse, 2001, s. 38).

In Brendan Hyde's applied research, it is observed that children in Godly Play classes were active participants in the 'spiritual quest'. After these lessons, it was seen that children were in search of meaning and purpose of life and some thoughts about what was important and valuable for children were developed. In addition, it has been seen that children develop a perspective in the fact that God is always with human beings (Hyde, 2010, s. 515).

In conclusion, although Godly Play has been criticized for lack of sufficient time and inadequacy in terms of acquiring some gains, it has been stated that this approach is generally a successful religious education practice. 